UDC 616-036.21: 614+316.42

DOI https://doi.org/10.26661/hst-2020-7-84-05

\title{
HEALTH CARE AS A GLOBAL PROBLEM OF HUMANITY AND ITS RELATIONSHIP WITH OTHER GLOBAL PROBLEMS
}

\author{
(C) PUNCHENKO, OLEG \\ Odessa State Academy of Technical Regulation and Quality (Odessa, Ukraine) \\ E-mail: olegpetr02.09@gmail.com \\ ODCID iD: http://orcid.org/0000-0003-2694-6841 \\ Одеська державна академія технічного регулювання та якості, вул. Ковальська, 15, 65020 Одеса, Украӥна \\ Odessa State Academy of Technical Regulation and Quantity, 15, Kovalska str., 65020 Odessa, Ukraine \\ (C) VORONKOVA, VALENTYNA \\ Engineering Educational and Research Institute of Zaporizhia National University (Zaporozhye, Ukraine) \\ E-mail: valentinavoronkova236@gmail.com, \\ ORCID iD: http://orcid.org/0000-0002-0719-1546 \\ Інженерний навчально-науковий інститут Запорізький національний університет, пр. Соборний, 226, \\ 69006 Запоріжжя, Україна \\ Engineering educational and scientific Institute of Zaporizhzhia National University, 226 Soborny Avenue, \\ 69006 Zaporozhye, Ukraine \\ C VODOP'YANOV, PAVEL \\ Belarusian State Technical University (Minsk, Republic of Belarus) \\ E-mail: pva1940@bk.ru \\ ORCID iD: http://orcid.org/0000-0002-7881-4114 \\ Білоруський державний університет, вул. Свердлова, 13 а, 220006 Мінськ, Республіка Білорусь \\ Belarusian State Technical University, 13a, Sverdlova str., 220006 Minsk, Republic of Belarus
}

\begin{abstract}
Relevance of the research. The relevance of the topic today is widely associated with humanity's struggle practice for its biological survival with the worldwide Covid-19. According to the World Health Organization, this is natural pathogen, but no one country - China or the United States - caused it to come to life - it is a product of the joint negative mankind activity in its relation to nature, ignoring the co-evolutionary interaction with it. It appeared as a global geo-, bio-, socio-, "quantum" of the planet Earth, negatively affecting not only the intellectual development of Homo Sapiens himself, but also sphere being - political, economic, financial, environmental, sociocultural, science, education, dramatically knocking down not only innovativeness in their forward movement, but also bringing chaos in the development of these spheres, and biological survival process grew into social fear. Negative impact analysis of Covid-19 give right today to include the health problem in the global mankind problems, along with environmental, demographic and other mankind problems, and it is necessary to substantiate the relationship of a new global problem with others, and do do not talk about it only when the world community is faced with epidemics and pandemics. The purpose is to substantiate healthcare as a global human existence problem, its relationship with other global problems. Research objectives: 1) to reveal the Covid-19 essence as a natural pathogen, as a combination of reasons for an existing way of life split, as a response and revenge to mankind for its predatory environmental management strategy; 2) to analyze self-organization possibility of public life in the context of coronavirus. Research methodology: it can be represented as a set of methods and approaches of modern methodological tools to explain the essence of the problem under research. The work includes: analysis and synthesis; historical and logical; abduction; genetic method; synergistic approach; generalizations; intelligent. Research results: 1) Covid-19 disclosed as geo-, bio-, social "quantum", negatively affecting the globalizing world transformation. Covid-19, as a natural pathogen, is explained as a natural revenge consequence against humanity for the predatory environmental management strategy; appeared as a response of nature to a reckless attitude towards it; as a process of ignoring the co-evolutionary mankind with nature connection, as a result of which the "pestilent" procession of the pandemic is sharply increasing throughout the world; the split is growing in all social life spheres. Covid-19 has sharpened the people's adaptation rhythm to kaleidoscopically globalizing world changing picture, introduced chaos into this picture of being, that develops into social fear and demanded a new social order self-organization. 2) The unfolding fight in the world against the coronavirus pandemic requires a real unification of countries in overcoming this pathogen. It is necessary to proceed not from political ambitions, but from moral, human ones, because we are not talking about the fate of some nation, nationality, but humanity as a whole. The practical significance of the topic in the need to form a strategy for mankind survival, in the center of which is the task of effectively combating various forms of epidemics, and today is the unification of the whole world to combat Covid-19. And, undoubtedly, the "first fiddle" in this struggle is played by health care as a global mankind problem.
\end{abstract}

Key words: Covid-19, healthcare, self-organization, "quantum", epidemic, strategy.

Health care as a global problem of humanity and its relationship with other global problems 


\section{Introduction}

\section{Relevance of the research.}

The relevance of the stated topic today is widely associated with humanity's struggle practice for its biological existence with the worldwide Covid-19. According to the World Health Organization, this is a natural pathogen, but no one country - China or the United States - caused it to come to life - it is a product of the joint negative mankind activity in its relation to nature, ignoring the co-evolutionary interaction with it. It appeared as a global geo-, bio-, socio-, "quantum" of the planet Earth, negatively affecting not only the intellectual development of Homo Sapiens himself, but also all life spheres - political, economic, financial, environmental, sociocultural, science, education, sharply knocking down not only innovativeness in their forward movement, but also introduced chaos in the development of these spheres, and the biological survival grew into social fear process. Negative impact analysis of Covid-19 gives right today to include the health problem in the global mankind problems, along with environmental, demographic and other mankind problems, and it is necessary to substantiate new global problem relationship with others, and do not talk about it only when the world community is with it collides.

The purpose is to substantiate healthcare as a global human existence problem, its relationship with other global problems. Research objectives: 1) to reveal the essence of Covid-19 as a natural pathogen and the reasons for the split in the existing way of life; 2) to analyze the coronavirus pandemic as nature's response to humanity for its predatory nature management strategy. Research methodology: a set of methods and approaches of modern methodological tools to explain the essence of the problem. The work includes: analysis and synthesis; historical and logical; abduction; genetic method; synergistic approach; generalization; intellectual (mental, comprehended only with the help of the intellect, which is given to the mind, but is absent in the feelings).

\section{Research results}

1. The essence of Covid-19 is characterized as a natural pathogen, as a geo-, bio-, social "quantum" that negatively affects human activity spheres. Covid-19 has become splitting globalization "startup", the reasons for this split are revealed. The current state characteristic of the globalizing world is given on the examples of political and economic problems. 2. The idea of the need to single out health care as a global humanity problem, which permeates all other global problems, as they are associated with the human factor, has been substantiated. The substantiation of this idea is confirmed by the factors of epidemics and pandemics that are constantly developing in the social space. The need for the world unity of the countries in the fight against Covid-19 has been proven, and for this, political ambitions must be discarded and through health care to develop strategy for the biological mankind survival [16].

The progress of mankind development has always been associated with different mastery forces of nature, through the improvement of labor tools. Movement analysis of human intellectual thought to materialize knowledge power from a hand to the creation and use of space technology, to the formation of a high technologic park: nano-, bio-, info-, cognitive technologies, gives the right to assert that "it is the mind that radically distinguishes a person from all living beings and allows him to overcome the limitations of natural existence in the surrounding world [18]. Therefore, health care must be included in the structure of the global problems of mankind. If earlier the various epidemics and pandemics that humanity experienced did not force us to really take care of the biological survival strategy of Homo Sapiens, then Covid-19 requires the development of this strategy, given that the global health problem permeates all other global problems: ecological, demographic, war and peace problem, the problem of terrorism and others; after all, the center these problems is a person and taking care of health is a priority in the global problems structure. At the same time, in the course of the reasonable people's needs satisfaction through the achievements of scientific and technological progress, the generation of the most acute global problems takes place [2]. The global problems of mankind include those that affect the interests of all mankind, that is, they have a largescale, universal human character, extremely acute and require a collective solution. All these problems are caused not only by scientific, technical, economic and technological processes, but have a social nature, since they are associated with obtaining maximum profit - the main goal of material and information production, with a predatory strategy of nature management and other negative processes. Global problems can today be classified articulated, lining up in the following directions [1].

First, the socio-political, especially aggravated in connection with the processes of globalization of the modern world; establishing a new world

(C) Punchenko, Oleg, Voronkova, Valentyna, Vodop'yanov, Pavel, 2021 
order and managing it; the split of political relations between the leading countries - the US, China, Russia and the EU and the impossibility of reaching a consensus between them at the present stage, which negatively affects the whole world and is a trigger (trigger) to restrain it in solving the global problem of war and peace [4]. Secondly, socioeconomic, associated with the struggle for sales markets, bringing social fear and impoverishment to the prevailing mass of the population. If the solution of socio-political problems constituted the main field of struggle on an ideological platform and did not imply the conduct of a major world war, then, as soon as the leaderships of the countries realized the scale of the collapse of infrastructure and the loss of labor, socio-economic problems began to be solved through the "bouquet" of negative impact of some countries to others. This "bouquet" includes: the deployment of conflicts; the imposition of sanctions and the search for methods to tame the obstinate countries; the use of "soft power", confrontation; aggravation of relations, up to crisis, etc. [13].

Thirdly, socio-ecological, reflecting a sharp violation of co-evolutionary co-development, coordination, interconnection and associated development of man and nature, that is, a mechanism that ensures the emergence of a new quality in relations with nature. It contains two requirements for the philosophy of ecology. The "first" is predetermined by the requirement to evaluate the peculiarities of modern ecology as a natural science ... and is associated with understanding both the place of man in the ecosystem of the biosphere and the peculiarities of human influence on the course of its cognition. Second, the inclusion of an axiological component in scientific knowledge - the definition of an ecological ethos, that is, a moral attitude towards nature. These problematic factors are components of a more general problem - the worldview aspects of modern ecology, the basis of which is the development of a strategy for the existence of mankind [7].

Globalization has expanded the sphere of negative impact on the environmental problem and, as a naturalhistorical process of human development, is the result of minor, unplanned and to a small extent predictable transformations in the economic, political and sociocultural life of society. As an artificial process, it includes elements of direct or disguised, purposeful, deliberate violence, i.e. attempts to impose, by force or other methods, one or another value-worldview, economic, political ideas and their corresponding decisions and directions of actions" [12].
Fourth, the social direction associated with the problems of demography, food security, the weakening of immune resources in humans, terrorism, the preservation of biodiversity in flora and fauna, and other concepts for the formation of global peace and overcoming global problems are many. However, it is one thing to develop theoretical constructs, to give advice on overcoming global problems, and another thing to practically solve them. Even M. Forbes, the son of C. Forbes, who founded the financial and economic magazine Forbes in 1917, wrote that "information for a person is advice. But you can earn much more by selling advice than by following it." This is probably why many countries, profiting from nature, are in no hurry to implement the concept of sustainable development approved in 1992 [9].

Many countries regarded a positive solution to the noted global problems proceeding from the realization of their aspirations and goals, which they associated with the unfolding globalization, ignoring the relationship between objective conditions and subjective factors. In the field of building global peace, the two systems identified by W. Churchill collided again. The theoretical constructs of globalists pushed the solution of global problems into the background, but stumbled over an underwater reef - Covid-19, which destroyed not only all these constructs, but also in practice brought serious destruction to the system of political, financial and economic relations, as well as negatively affected a number of spheres of social life of mankind, such as science, education, spiritual culture [12].

The main positive was the mankind appeal to health care problem, to substantiate the strategy of its biological survival. Covid-19 has become a negative "start-up" for the split of the globalizing world, and according to the WHO, it is a natural pathogen, and it is necessary to fight it through close cooperation between countries. Humanity has repeatedly encountered pandemics and epidemics and it can be argued that they forced humanity to look for the causes of their occurrence and the means of combating them. The civilizational history of mankind, from the standpoint of a negative factor, can be investigated by the "plague procession" of epidemics and pandemics, such as plague, ulcers, fever and influenza in their various forms, smallpox, cholera, diphtheria, AIDS, and today-Covid-19. The number of cases worldwide in April 2021 is more than 30 million people. However, it is impossible to blame nature for everything, to blame all the troubles 
on objective conditions, the subjective factor also makes a big contribution. "These and other diseases, noted P. Vodopyanov and V. Krisachenko, - are caused by the growing pollution of the environment, as a result of which the rate and speed of biological evolution change, and therefore it can be assumed that infectious diseases will grow at an exponential rate. The successes of medicine cannot overshadow the indisputable fact that a person is not able to change the laws of evolution of the biosphere without harm to himself" [3].

Covid-19 gives humanity a chance to grow wiser in relationship with nature. It appeared as a global geo-, bio-, social "quantum" of negative impact on socioeconomic, co-evolutionary and medical processes, as a response of nature to man's attitude towards it, as her revenge on humanity for its predatory strategy of nature management. The concept of "quantum" is used to research and understand the foundations of most social macro formations. Covid-19 negatively changes our daily activities [15].

It sharply sharpened the rhythm of human adaptation to the conditions of life in the global world. In the context of the coronavirus pandemic, humanity must unite in the face of its threats, but this is hampered by the ambitious projects of globalists who continue to build walls, rather than build bridges between countries to save humanity. Even in conditions of high morbidity and mortality, the political ambitions of the leadership of individual countries come to the fore. This is confirmed today by the processes of vaccination in the world community. And until the strategy for the survival of mankind is put to the fore, until health care is recognized as a global challenge for mankind, Covid-19 will continue its deadly march around the world [5].

Epidemic and pandemic analysis of mankind life allowed A.Chumakov to argue that today "the health problem has to overcome not only local, but also regional boundaries and reached the global level" [19]. That is, health care is moving into the rank of a global mankind problem, the main task is to find ways and strategies for the mankind survival along with environmental, demographic, war and peace problems, terrorism and others, because they all are related to the human factor, and health care acts as cementing principle interconnection of global mankind problems. We have not forgotten that health care, medicine, as a branch of scientific knowledge, is associated with the mind formation. It is embodied in the medical mankind research and must be attributive and moral. Then development process of the no-sphere will act as an undoubted benefit, which brings to mankind solution of the most complex problems. "However, the social mankind practices in XX - early. XXI centuries demonstrates not so much harmony as the crisis of relations between man and nature and forces a critical assessment of the achievements and mankind prospects in the field of so-called NBJC-technologies ... radically changing not only the bio- and no-sphere, but also the nature of man himself" [8].

But the question arises: where to start justifying health care as a determinant entire set of global mankind problems? To paraphrase A. Chumakov to the new world order question [19], it can be argued that health care issue is as ancient as the world of public relations in which we live ... the health care question arose every time, as soon as the world community once again experienced an epidemic or pandemic coming close to their line. Today, Covid-19 has entered as this feature, which has made a split in all processes of the globalizing world: politics; the economy; finance; social sphere; into the global mankind problems and demanded a constructive self-organization of social life and led to "slag globalization" (its decline) [10]. According to G. Shcherbakov in the article "Impact and consequences of the COVID-19 pandemic: the socio-economic dimension", "The cause of the coronavirus has become the beginning of the global transformation of the modern world. The world community is expecting big changes in the near future, as well as long-term consequences, which are still difficult to predict. However, at the same time, the pandemic opens up new opportunities, including the path to a more harmonious society" [20, p. 17].

The theoretical constructs of self-organization are embedded in the synergetic approach. From the standpoint of its application, self-organization appears as "a concept that characterizes the most important property of the objective world (systems), its ability for internal self-organization in the event of a change in external conditions of existence that prevent these systems from achieving a stable position in this environment. Self-organization ... - the ability of systems of different nature ... to spontaneous, internally determined activity in the direction of the growth of their organization in the emerging negative environment of existence. To characterize complex social systems, science identifies a number of modes of functioning: the first one reflects constructive progressive development; the second reflects the regression (decline) of development; the third reflects one-sided develop-

(C) Punchenko, Oleg, Voronkova, Valentyna, Vodop'yanov, Pavel, 2021 
ment; the fourth reflects stagnation, turning into stagnation of the system. Today, the second and fourth modes of functioning of the social system have united into a single whole. With regard to the current state of society, today "the stagnation regime can be characterized by the following indicators: a low level of collective intelligence; weak implementation of social innovations; blurring of moral, legal and other norms; isolation of certain social groups and institutions; lack of spirituality; orientation of members of society mainly to stereotypical patterns of action in various spheres and lack of orientation towards moving forward" [11].

Yes, today there is stagnation in the progressive development of all spheres of human activity. But in 3-4 years the economies of the leading countries of the world will stabilize; the problems of financial relations between the countries will be resolved; in politics, in connection with globalization, and it will not go into the annals of history, it will be difficult to reach a consensus, but a big war between the leading countries is impossible, since it will destroy the infrastructure of countries and destroy the labor force even before the robotization of industrial, agricultural production, the social sphere. Undoubtedly, the pandemic will go into the annals of human history, but it will force him to reconsider the strategy of human survival, and this is the task of public health [17].

\section{Conclusions}

Today humanity lives in two dimensions: globalization, associated with the global world formation by violent means - the collision of strong powerful interests, the use of "soft power", sanctions, confrontation development, everything that intensifies the crisis in all human existence spheres and gives rise to a new VUCA concept.
Theoretically, the formation of the global world, only in subjective factor was taken into account, no attention was paid to the objective natural conditions, which intensified the negatively on global mankind problems and brought to life its second dimension the test of a pandemic. Covid-19 appeared as a natural pathogen, prepared not by one country, but by the negative attitude of all mankind towards nature. And he acted as a response of nature, its revenge, for the predatory strategy of nature management. But the positive of the coronavirus pandemic lies in justifying the role of healthcare, introducing it into the global problems of mankind, without a positive solution to which it will not survive, since the strategy of its existence can only be entrusted to real cooperation of all countries in the field of healthcare. We must agree with G. Shcherbakov that the spread of the SarS-Cov-2 virus and the measures taken by national governments to contain it have practically closed all discussions about the prospects for globalization, which until recently was considered the main direction of development of the world economy. The fundamental dignity of globalization should, in the opinion of its supporters, lie in the fact that it allows consolidating the efforts of the world community in the facing threats and challenges, including epidemics and pandemics [20, p. 16-17].

The practical significance of the research lies in the fact that the idea is put forward, and a justification is given to it, including health care in the global mankind problem as determining one. This is confirmed by the epidemic and pandemic facts experienced by mankind, and today Covid-19 is marching around the world and countries need to collectively develop a new concept for the struggle for mankind survival.

\section{Список використаних джерел}

1. Andriukaitiene Regina, Voronkova V., Kyvliuk O. \& Nikitenko V. (2017). Formation and development of smart society as high-minded, high-tech and high-intelligent community. Humanities Bulletin of Zaporizhzhe State Engineering Academy. Toм 71. C. 17-25.

2. Andriukaitiene Regina, Cherep A., Voronkova V. Punchenko O. \& Kivliyk O. (2018). Managing organizational culture as a factor in organizational change. Humanities Bulletin of Zaporizhzhe State Engineering Academy: Proceedings Scientific publications / Ed. V. Voronkova. Zaporizhzhie: EPD of ZSEA. Issue 75. P. 169-179.

http://vestnikzgia.com.ua/article/view/155562

3. Водопьянов П.А. \& Крисаченко В.С. (2018). Стратегия бытия человечества. Минск: Беларуская навука.

4. Воронкова Валентина, Пунченко Олег \& Пунченко Наталия (2019). Мегатренды информационнокомпьютерных технологий как проявление глобальных тенденций развития цифрового мира. Theory and practice: problems and prospects. Scientific articles.Lietuvos sporto universitetas, 2019. 244-252.

https://www.lsu.lt/wp-content/uploads/2019/07/Mokslas-ir-praktika-2019-Straipsniu-rinkinys.pdf

5.Voronkova Valentyna, Punchenko Oleg \& Azhazha Marina (2020). Gglobalization and global governance in the fourth industrial revolution (Industry 4.0). HUMANITIES STUDIES: збірник наукових праць / Гл. ред. В. Г. Воронкова. Запоріжжя : ЗНУ, 2020. Вип. 4 (81). 182-200.DOI: https://doi.org/10.26661/hst-2020-4-81-11 
6. Danilov Aleksandr. To the technology of civilizational development: updating the cultural code content. Humanities Studies. Запоріжжя : ЗНУ, 2020. Випуск 3(80). С. 22-29.

7. Воронкова Валентина, Кивлюк Ольга, Нікітенко Віталіна, Рижова Ірина. Stem-освіта як фактор становлення i розвитку smart-суспільства. Становлення і розвиток інформаційного суспільства як основи забезпечення конкурентоспроможності України у світі та сталого розвитку суспільства і держави». Матеріали Міжнародної науково-практичної конференції 23-24 листопада 2017 року / Ред.-упорядник: д.філософ.н., проф. В.Г. Воронкова. Запоріжжя: Вид-во ЗДІА, 2017. - 276 с. С. 81-84.

8. Запорожан В.Н., Донникова И.А. \& Ханжи В.Б. (2020). Между добром и злом: нравственное самоопределение человека. Одесса: Одесский медуниверситет.

9. Nikitenko Vitalina. Evolution and further development of the real world in the conditions of technological changes in the context of socio-philosophical discourse. Humanities Studies. Запоріжжя : ЗНУ, 2020. Випуск 4(81). С. 60-73.

10. Oleksenko Roman. Position and role of modern economic education as the main megatrend of innovative development of Ukraine. HUMANITIES STUDIES: Collection of Scientific Papers / Ed. V. Voronkova. Zaporizhzhia : ZNU, 2020. 2 (79). C. 169-181.

11. Punchenko Oleg, Punchenko Natalia. Basic strategic technology of intellectual duality of humanity in information technology. HUMANITIES STUDIES: Collection of Scientific Papers / Ed. V. Voronkova. Zaporizhzhia : ZNU, 2019. Випуск 2(79). С. 95-114.

12. Пунченко О.П. (2014). Цивилизационное измерение истории человечества. Одесса: Астропринт.

13. Punchenko, O. Voronkova, V., Andriukaitiene, Regina. Sociodynamics of the globalizing world in its civilization dimension. Гуманітарний вісник Запорізької державної інженерної академії. Запоріжжя. 2018. Вип. 74. 48-60. DOI: https://doi.org/10.30839/2072-7941.2018.149652

http://vestnikzgia.com.ua/article/view/149652

14. Punchenko Oleg, Voronkova Valentina, \& Vodop'yanov Pavel. New enlichtemment new fractality in transformation process of education. HUMANITIES BULLETIN of Zaporizhzhe State Engineering Academy: Proceedings Scientific publications / Zaporizhzhia: EPD of ZSEA. 2019. Issue 77. 144-159.

DOI: https://doi.org/10.30839/2072-7941.2019.177746

15. Пунченко Олег, Ангдрюкайтене Регина, \& Воронкова Валентина. Влияние технологий на жизнь человека в цифровую эпоху машин и их роль в развитии общества. Theory and practice: problems and prospects Scientific articles. Kaunas 2020. 357-366.

http://www.tsatu.edu.ua/vmf/wp-content/uploads/sites/17/sobranye-statej_2020_kaunas-maryjampole-1.pdf

16. Пунченко О.П. \& Воронкова В.Г. Цивилизация как глобальный «квант» уникального бытия человечества. Сборник научных трудов «филосфские исследования». № 7. Минск: Институт философии НАН Беларуси, Беларуская навука, 2020. 80-95. http://philosophy.by/wp-content/store/philosophical-studies-nr-7.pdf

17. Пунченко Олег, Воронкова Валентина \& Пунченко Наталия. Концептуальная модель «нового просвещения» как фактор развития трансформационных процессов в образовании. Mokslas ir praktika: aktualijos ir perspektyvos Taptautinė mokslinė - praktinė konferencija 2019 m. gegužès 09-10 may, Kaunas Tezių rinkinys (internete). 2019. 66-67

18. Cherep Alla, Voronkova Valentyna, Muts Luai Faisal \& Fursìn Alexander Information and innovation technologies as a factor of improving the efficiency of digital economy and business in the Globalization 4.0. Humanities Studies. Запоріжжя : ЗНУ, 2019. Випуск 1(78). С. 170-181.

19. Чумаков А.Н. (2020). Глобализация в контексте современности: испытание пандемией. Москва : Век глобализации. № 3 .

20. Щербаков Г.А. Влияние и последствия пандемии COVID-19: социально-экономическое измерение. МИР (Модернизация. Инновации. Развитие). 2021. Т. 12. № 1. С. 8-22.

\section{References}

1. Andriukaitiene Regina, Voronkova V., Kyvliuk O. \& Nikitenko V. (2017). Formation and development of smart society as high-minded, high-tech and high-intelligent community. Humanities Bulletin of Zaporizhzhe State Engineering Academy. Tom 71. C. 17-25.

2. Andriukaitiene Regina, Cherep A., Voronkova V. Punchenko O. \& Kivliyk O. (2018). Managing organizational culture as a factor in organizational change. Humanities Bulletin of Zaporizhzhe State Engineering Academy: Proceedings Scientific publications / Ed. V. Voronkova. Zaporizhzhie: EPD of ZSEA. Issue 75. P. 169-179.

http://vestnikzgia.com.ua/article/view/155562

3.Vodopyanov P. \& Krisachenko V. (2018). The strategy of human existence. Minsk: Belarusian Navuka.

4. Voronkova Valentina, Punchenko Oleg \& Punchenko Natalia (2019). Megatrends of information and computer technologies as a manifestation of global trends in the development of the digital world. Theory and practice: problems and prospects. Scientific articles.Lietuvos sporto universitetas, 2019. 244-252.

https://www.lsu.lt/wp-content/uploads/2019/07/Mokslas-ir-praktika-2019-Straipsniu-rinkinys.pdf

(C) Punchenko, Oleg, Voronkova, Valentyna, Vodop'yanov, Pavel, 2021 
5. Voronkova Valentyna, Punchenko Oleg \& Azhazha Marina (2020). Gglobalization and global governance in the fourth industrial revolution (Industry 4.0). HUMANITIES STUDIES: collection of scientific works / Ch. ed. V. Voronkova. Zaporizhzhia: ZNU, 2020. Issue 4 (81). 182-200.

DOI:https://doi.org/10.26661/hst-2020-4-81-11

6. Danilov Aleksandr. To the technology of civilizational development: updating the cultural code content. Humanities Studies. Zaporizhzhia: ZNU, 2020. Issue 3(80). 22-29.

7. Voronkova Valentina, Kivlyuk Olga, Nikitenko Vitalina, Ryzhova Irina. Stem-education as a factor in the formation and development of smart-society. Formation and development of the information society as a basis for ensuring Ukraine's competitiveness in the world and sustainable development of society and the state. " Proceedings of the International Scientific and Practical Conference on November 23-24, 2017 / Editor-in-Chief: Doctor of Philosophy, Prof. V. Voronkova. - Zaporizhzhia: ZDIA Publishing House, 2017. - 276 p. P. 81-84.

8. Zaporozhan V., Donnikova I. \& Khanzhi V. (2020). Between good and evil: moral self-determination of man. Odessa: Odessa Medical University.

9. Nikitenko Vitalina (2020). Evolution and further development of the real world in the conditions of technological changes in the context of socio-philosophical discourse. Humanities Studies. Zaporizhzhia: ZNU, 2020. Issue 4(81). 60-73.

10. Oleksenko Roman (2020). Position and role of modern economic education as the main megatrend of innovative development of Ukraine. HUMANITIES STUDIES: Collection of Scientific Papers / Ed. V. Voronkova. Zaporizhzhia : ZNU. 2 (79). 169-181.

11. Punchenko Oleg, Punchenko Natalie (2019). Basic strategic technology of intellectual duality of humanity in information technology. HUMANITIES STUDIES: Collection of Scientific Papers / Ed. V. Voronkova. Zaporizhzhia: ZNU. Issue 2(79). 95-114.

12. Punchenko O. (2014). Civilizational dimension of human history. Odessa: Astroprint.

13. Punchenko, O. Voronkova, V. Andriukaitiene, Regina.Sociodynamics of the globalizing world in its civilization dimension. Humanitarian Bulletin of the Zaporizhia State Engineering Academy. Zaporizhzhia: 2018. Issue 74. 48-60.

DOI: https://doi.org/10.30839/2072-7941.2018.149652

http://vestnikzgia.com.ua/article/view/149652

14. Punchenko Oleg, Voronkova Valentina, \& Vodop'yanov Pavel (2019). New enlichtemment new fractality in transformation process of education. HUMANITIES BULLETIN of Zaporizhzhe State Engineering Academy: Proceedings Scientific publications / Zaporizhzhia: EPD of ZSEA. 2019. Issue 77. 144-159.

DOI: https://doi.org/10.30839/2072-7941.2019.177746

15. Punchenko Oleg, Angdrukaitene Regina, \& Voronkova Valentina (2020). The impact of technology on human life in the digital age of machines and their role in the development of society. Theory and practice: problems and prospects Scientific articles.Kaunas 2020. 357-366.

http://www.tsatu.edu.ua/vmf/wp-content/uploads/sites/17/sobranye-statej_2020_kaunas-maryjampole-1.pdf

16. Punchenko O. \& Voronkova V. (2020). Civilization as a global "quantum" of the unique being of mankind. Collection of scientific works "philosophical research". № 7. Minsk: Institute of Philosophy of the National Academy of Sciences of Belarus, Belaruskaya Navuka,2020.80-95.

http://philosophy.by/wp-content/store/philosophical-studies-nr-7.pdf

17. Punchenko Oleg, Voronkova Valentina \& Punchenko Natalie (2019). Conceptual model of "new enlightenment" as a factor in the development of transformational processes in education. Science and Practice: Current Issues and Perspectives International Scientific-Practical Conference, 2019. Collection of theses (online). 66-67

18. Cherep Alla, Voronkova Valentyna, Muts Luai Faisal \& Fursìn Alexander. Information and innovation technologies as a factor of improving the efficiency of digital economy and business in the Globalization 4.0. Humanities Studies. Zaporizhzhia: ZNU. 2019. Issue 1(78). 170-181.

19. Chumakov A. (2020). Globalization in the context of modernity: a pandemic test. M.: The Age of Globalization. Number 3.

20. Shcherbakov G. Impact and Consequences of the COVID-19 Pandemic: Socio-Economic Dimension. MID (Modernization. Innovation. Development). 2021. T. 12. № 1. 8-22.

ПУНЧЕНКО, О. П. - доктор філософських наук, професор, професор кафедри стандартизації, оцінки відповідності та освітніх вимірювань, Одеська державна академія технічного регулювання та якості (Одеса, Україна)

E-mail: olegpetr02.09@gmail.com

ORCID iD: https://orcid.org/0000-0009-2694-6841

Health care as a global problem of humanity and its relationship with other global problems 
ВОРОНКОВА, В. Г. - доктор філософських наук, професор, Академік академії наук вищої освіти України, завідувач кафедри менеджменту організацій та управління проєктами, Інженерний навчальнонауковий інститут Запорізького національного університету (Запоріжжя, Україна)

E-mail: valentinavoronkova236@gmail.com

ORCID iD: http://orcid.org/0000-0002-0719-1546

ВОДОП'ЯНОВ, П. О. - доктор філософських наук, професор, професор кафедри філософії і права, Білоруський державний технологічний університет, член-кореспонедент Національної академії Беларусі (Мінськ, Республіка Білорусь)

E-mail: pva1940@bk.ru

ORCID iD: http://orcid.org/0000-0002-7881-4114

\title{
ОХОРОНА ЗДОРОВ'Я ЯК ГЛОБАЛЬНА ПРОБЛЕМА ЛЮДСТВА ТА ЇЇ ВЗАЄМОЗВ'ЯЗОК З ІНШИМИ ГЛОБАЛЬНИМИ ПРОБЛЕМАМИ
}

\begin{abstract}
Анотація
Актуальність теми дослідження. Актуальність теми сьогодні широко пов'язана з практикою боротьби людства за своє біологічне виживання й охопила весь світ. За заявою Всесвітньої організації охорони здоров'я, Covid-19 це природний патоген, що розповсюджується не в одній країні - Китаї або США, - це продукт спільної негативної діяльності людства в його ставленні до природи, ігнорування коеволюційної взаємодії з нею. Covid-19 розглядається як глобальний гео-, біо-, соціо-, «квант» планети Земля, що негативно впливає не тільки на інтелектуальний розвиток самого Нomo Sapiens, а й сфери його буття - політичної, економічної, фінансової, екологічної, соціокультурної, науки, освіти, різко зменшивши не тільки інноваційність в їх поступальному русі, але і внісши хаос у розвиток цих сфер, а у процесі біологічного виживання переріс у соціальний страх. Аналіз негативного впливу Covid-19 дає право сьогодні включити проблему охорони здоров'я у глобальну проблему людства поряд з екологічними, демографічними та іншими проблемами людства, і тому необхідне обгрунтування взаємозв'язку нової глобальної проблеми з іншими, а не обговорення іії тільки тоді, коли світова спільнота стикається з епідеміями і пандеміями. Мета дослідження - обгрунтувати охорону здоров'я як глобальну проблему буття людства, показати іï взаємозв'язок з іншими глобальними проблемами. Завдання дослідження: 1) розкрити сутність Covid-19 як природного патогена, сукупність причин розколу сформованого укладу життя, як відповідь і помста людству за його хижацьку стратегію природокористування; 2) проаналізувати можливість самоорганізації суспільного життя в умовах коронавирусу. Методологія дослідження: іiі можна репрезентувати як сукупність методів і підходів сучасного методологічного інструментарію для пояснення сутності досліджуваної проблеми. До методів у роботі слід віднести: аналіз і синтез; історичне і логічне; абдукцію; генетичний метод; синергетичний підхід; узагальнення; інтелігібельність. Результати дослідження: 1) Розкрито Covid-19 як гео-, біо-, соціальний «квант», що негативно впливає на трансформацію глобалізованого світу. Covid-19, як природний патоген, закономірний наслідок помсти людству за хижацьку стратегію природокористування; постав, як відгук природи на безпорадне ставлення до неї; як процес ігнорування коеволюційного зв'язку людства 3 природою, у результаті чого різко зросло «вимирання населення» у ході пандемії по всьому світу; посилився розкол у всіх сферах суспільного буття. Covid-19 загострив ритм пристосування людей до калейдоскопічно мінливої картини глобалізованого світу, вніс у цю картину буття хаос, який переріс у соціальний страх і зажадав нової самоорганізації суспільного устрою. 2) Розгорнута боротьба у світі з пандемією коронавируса вимагає реального об’єднання країн в подоланні цього патогена. Необхідно виходити не з політичних амбіцій, а з моральних, людських, адже мова йде не про долю якоїсь нації, народності, а людства у цілому. Практичне значення теми - у необхідності формування стратегії виживання людства, у центрі якої - завдання ефективної боротьби з різними формами епідемій, а сьогодні - об'єднання всього світу для боротьби з Covid-19. I, безсумнівно, «першу скрипку» у цій боротьбі відіграє охорона здоров'я як глобальна проблема людства.
\end{abstract}

Ключові слова: Covid-19, охорона здоров’я, самоорганізація, «квант», епідемія, стратегія.

ПУНЧЕНКО, О. П. - доктор философских наук, профессор, профессор кафедры стандартизации, оценки соответствия и образовательных измерений, Одесская государственная академия технического регулирования и качества (Одесса, Украина)

E-mail: olegpetr02.09@gmail.com

ORCID iD: https://orcid.org/0000-0003-2694-6841

(C) Punchenko, Oleg, Voronkova, Valentyna, Vodop'yanov, Pavel, 2021 
ВОРОНКОВА, В. Г. - доктор философских наук, профессор, Академик академии наук высшего образования Украины, заведующая кафедрой менеджмента организаций и управления проектами, Инженерный учебно-научный институт Запорожского национального университета (Запорожье, Украина)

E-mail: valentinavoronkova236@gmail.com

ORCID iD: http://orcid.org/0000-0002-0719-1546

ВОДОПЬЯНОВ, П. А. - доктор философских наук, профессор, профессор кафедры философии и права, Белорусский государственный технологический университет, член-корреспондент Национальной академии наук Беларуси (Минск, Республика Беларусь)

E-mail: pva1940@bk.ru

ORCID iD: http://orcid.org/0000-0002-7881-4114

\title{
ЗДРАВООХРАНЕНИЕ КАК ГЛОБАЛЬНАЯ ПРОБЛЕМА ЧЕЛОВЕЧЕСТВА И ЕЕ ВЗАИМОСВЯЗЬ С ДРУГИМИ ГЛОБАЛЬНЫМИ ПРОБЛЕМАМИ
}

\begin{abstract}
Аннотация
Актуальность темы исследования. Актуальность темы сегодня широко связана с практикой борьбы человечества за свое биологическое выживание, с охватившим весь мир вирусом Covid-19. По заявлению Всемирной организации здравоохранения, это природный патоген, но вызвала его к жизни не одна страна - Китай или США, - это продукт совместной негативной деятельности человечества в его отношении к природе, игнорирование коэволюционного взаимодействия с ней. Он предстал как глобальный гео-, био-, социо-, «квант» планеты Земля, негативно влияющий не только на интеллектуальное развитие самого Homo Sapiens, но и сферы его бытия - политической, экономической, финансовой, экологической, социокультурной, науки, образования, резко сбив не только инновационность в их поступательном движении, но и внеся хаос в развитие этих сфер, а процессе биологического выживания перерос в социальный страх. Анализ негативного воздействия Covid-19 дает право сегодня включить проблему здравоохранения в списое глобальных проблем человечества, наряду с экологическими, демографическими и другими проблемами. Требуется необходимость обоснования взаимосвязи новой глобальной проблемы с другими, а не говорить о ней только тогда, когда мировое сообщество сталкивается с эпидемиями и пандемиями. Цель исследования обосновать пандемию Covid-19 как глобальную проблему человечества, ее взаимосвязь с другими глобальными проблемами. Задачи исследования: 1) раскрыть сущность Covid-19 как природного патогена, как причину раскола сложившегося уклада жизни, как ответ и месть человечеству за его хищническую стратегию природопользования; 2) проанализировать возможность самоорганизации общественной жизни в условиях коронавируса. Методология исследования: ее можно репрезентировать как совокупность методов и подходов современного методологического инструментария для объяснения сущности исследуемой проблемы. К нему в работе отнесены: анализ и синтез; историческое и логическое; абдукция; генетический метод; синергетический подход; обобщения; интеллигибельность. Результаты исследования: 1) раскрыта сущность Covid-19 как гео-, био-, социального «кванта», негативно влияющего на трансформации глобализирующего мира. Covid-19, как природный патоген, объяснен как закономерное следствие мести человечеству за хищническую стратегию природопользования; он предстал как отклик природы на безрассудное отношение к ней; как процесс игнорирования коэволюционной связи человечества с природой, в результате чего резко возросло «мировое» шествие пандемии; усилился раскол во всех сферах общественного бытия. Covid-19 обострил ритм приспособленности людей к калейдоскопически меняющейся картине глобализированного мира; он внес в эту картину бытия хаос, который перерос в социальный страх и потребовал новой самоорганизации общественного устройства. 2. Развернувшаяся борьба в мире с пандемией коронавируса требует реального объединения стран в преодолении этого патогена. Необходимо исходить не из политических амбиций, а из нравственных, человеческих, ведь речь идет не о судьбе какой-то нации, народности, а человечества в целом. Практическое значение темы - в необходимости формирования стратегии выживания человечества, в центре которой - задачи эффективной борьбы с различными формами эпидемий, а сегодня - объединение всего мира для борьбы с Соvid-19. И, несомненно, «первую скрипку» в этой борьбе играет здравоохранение.
\end{abstract}

Ключевые слова: Covid-19, здравоохранение, самоорганизация, «квант», эпидемия, стратегия.

(C) The Author(s) 2021

This is an open access article under the Creative Commons CC BY license
Received date 01.03 .2021

Accepted date 12.03.2021

Published date 21.03.2021

How to cite: Punchenko, Oleg, Voronkova, Valentyna \& Vodop'yanov, Pavel. Health care as a global problem of humanity and its relationship with other global problems. Humanities studies: Collection of Scientific Papers. Zaporizhzhia: Zaporizhzhia National University, 2021.7 (84), P. 39-47.

doi: https://doi.org/10.26661/hst-2020-7-84-05

Health care as a global problem of humanity and its relationship with other global problems 